\title{
Old Times' Sake as a Moral Category
}

\author{
- Yotam Benziman -
}

\begin{abstract}
In this paper I discuss the notion of old times' sake, one which is hardly discussed by moral philosophers, and claim that it serves as a moral reason for us to act on behalf of the people we used to cherish: former friends, colleagues, neighbors, or spouses. While our relationship with them has ended, the building-blocks of our identity will continue to bear their fingerprints, and they will ever be an important part of our biography. Acting for old times' sake reflects both our caring about them, and our caring about our own past, biography, and accumulated identity. Why the relationship has ceased will of course affect our attitude towards them. Although old times' sake might not always be a decisive factor, it still serves as a moral reason for action.
\end{abstract}

Keywords: ethics, old times' sake, personal relations, friendship, identity, memory.

Published online: 14 June 2020

Pete and I used to be close friends. We were in our twenties - the age of formative decisions: whom should I choose as a partner to share my life with? Which profession should I pursue? Where should I live? We would discuss these questions with one another. We confided in each other, and spent much time together. We were very meaningful to one another. As the years passed, we drifted apart. Nothing dramatic happened. It's not that we have quarreled. Each of us has been leading his own life in the course he has chosen. We live in different cities, we never meet, we are not friends anymore. By mere chance, I hear that Pete is suffering from a fatal disease. I feel obligated to come and visit, to see if I can do anything for Pete and his family, at least to talk once again, perhaps for the last time, about the meaningful time we spent together all those years ago. But am I really obligated to do this?

In what follows I will refer to the feeling that I ought to do something for Pete because of our shared past, as a feeling that belongs in the category of "old times' sake." This coheres with our regular use of the term. When you do something for old times' sake, you relate to a memory of past experiences that you cherish and are happy with. Thus, if the experiences I shared with Pete were ones that now, as a more mature person, I am ashamed of, they would not incline me to do something for him for old times' sake in the sense I am using the term. But supposing that I do value the activities that Pete

Yotam Benziman

The Department of Multidisciplinary Studies, The Department of Public Management and Policy Sapir Academic College, Ashkelon Beach Mobile Post, Shaar Hanegev 7915600, Israel email: Yotam.benziman@mail.huji.ac.il 
and I shared a long time ago, and hence feel that I ought to do something for him, is this sentiment grounded on anything? Is old times' sake a moral category?

This question was hardly discussed among philosophers. To the best of my knowledge, the only one to put forward old times' sake as a reason for moral action was Jeffrie Murphy, suggesting it as a motive for "forgiving a person who has willfully wronged me." ${ }^{1}$ Norvin Richards criticizes Murphy, claiming that "although [he] says here that we can properly forgive people for old times' sake, for what they once were for us, he does virtually nothing to explain why." 2 In his own attempt to explain why, Richards emphasizes the values of friendship, rather than the category of old times' sake per se. In fact, his analysis suggests that friendship "is a reason to suppose that you have one of the other reasons to forgive" (the others being excuses, good intentions or repentance of the wrongdoer). "That," he goes on to say, "is not the same as old times' sake being a reason in itself, of course. And, it is less compelling for the merely former friend than for the current one." ${ }^{3}$

Richards' point is valid not only for forgiveness, but for other attitudes as well. Our current relationships provide us with reasons for attitudes or actions that are stronger than the ones called for, if at all, by our past ones. Had Pete and I still been good friends, there would have been no question of my standing by him in the dire situation of his illness. Our relationship would demand it. But as we have no relationship at all, it seems that the answer to the question whether old times' sake is a moral category should simply be: 'no'. Bygones are bygones, and we have no business to revive them.

Yet my claim in this paper is that old times' sake should be regarded as a moral category. Consider the following: suppose that the information I come by does not concern Pete's being ill, but rather his death. The question facing me is not, as in the previous case, whether to contact him. He cannot be contacted anymore. The issue here is whether or not I should attend his funeral. And here, it seems to me, many of us would reply in the affirmative. Why so? The answer is clear enough: funerals are about bygones.

I come to Pete's funeral because he played an important part in my life. I cared for him and he cared for me. The interaction we used to have helped shape some significant parts of my identity. I pay tribute to him for the impact he has had on me. I cherish his memory. Our obligations to remember the dead are grounded on our relationships with them. Both Avishai Margalit and Jeffrey Blustein, while addressing the morality or ethics of memory, ${ }^{4}$ build on this notion. As Margalit has it, "to say that I expect you to remember me is to say that you should remember me, if our relations now are as thick as I believe them to be. This is not a prediction but a prescription. We address such normative expectations to those with whom we have thick personal relations." ${ }^{5}$ And as Blustein puts it, when talking about a friend, Bill, who has suddenly passed away, "Bill died when our relationship was still close, when we both believed (correctly) that

\footnotetext{
1 Murphy (1982): 508.

2 Richards (1988): 92.

${ }^{3}$ Ibidem: 93.

4 Margalit distinguishes between morality, which he ascribes to our "thin" relations, and ethics, which he ascribes to our "thick" ones. Blustein uses the terms interchangeably.

${ }^{5}$ Margalit (2002): 93.
} 
there was a special bond between us. The relationship, but not the caring, ended when he died, with no possibility of further communication between us or evolution in our relationship." 6

Bill is an exemplar of what Blustein refers to as "the dear departed." He is portrayed as a close friend. Close friends are among the people with whom we have "thick personal relations" in Margalit's terminology. But Pete, in our example, is a person I have no relationship with whatsoever. We had a relationship, but it ended long ago. Pete is not a "dear" who has departed, and his relationship with me is not "thick" at all. He can make no "prescription" regarding my remembering him.

And yet, I do remember, and I do care. My attending his funeral is a manifestation of this fact. But the reasons for my attendance should also hold for my general attitude towards him, and not only for going to his funeral. Let's recall them: "He played an important part in my life. I cared for him and he cared for me. The interaction we had helped shape some significant parts of my identity." Pete is forever to remain part of my biography. To a certain extent, the building-blocks of my identity will continue to bear his fingerprints.

Our friendships play a crucial role in the formation of who we are. This has been acknowledged in many philosophical analyses of friendship. Thus, for example, Dean Cocking and Jeanette Kennett describe friends as "each other's creators." ${ }^{7}$ Sarah Stroud says that "to be someone's friend is to have cast your lot in with his and, indeed, with his good character; and this properly affects how you respond to new situations and new data." ${ }^{8}$ Anne-Laure Crépel defines friendship as "a relationship based on mutual affection and benevolence between two individuals who share common interests and thus partly live together." ${ }^{\prime}$ Anthony Carreras, while discussing Aristotle's notion of the friend as "another self," claims that "in friendship, the shaping goes in both directions. Each friend is at once both the shaper and the shaped." 10 These analyses stress the friends' inter-connectedness, and the way in which they depend on one another for the very forming of who they are.

Friendship thus construed is a powerful tool for the building of character. And it is clear that this power is indeed dependent upon the on-going relationship. When our friends are no longer friends, but rather ex-friends, we cannot claim that they continue to be our "creators," that we "cast our lots in with theirs," or that we "partly live together." What the notion of an ex-friend means is that we do not "live together" anymore. Having ceased to be close, does anything remain?

Our memories remain, of course. But memories of what? Acknowledging oldtimes' sake is not only a nostalgic, not-necessarily-called-for, gesture. What we remember when our friends have departed is the undeniable fact that our identities were shaped through our relationship with them. This will remain true even if we are no longer close. In this sense, our old relationships will forever be part of us.

\footnotetext{
6 Blustein (2008): 244.

7 Cocking, Kennett (1998): 509.

8 Stroud (2016): 512.

9 Crépel (2014): 184.

10 Carreras (2012): 327.
} 
There is something misleading about Blustein's description of friendship. He begins his Bill-example by discussing a friendship that came to an end not by the death of one of the partners, but rather as a result of what happened to both parties while still alive. He says that "the responsibilities of friendship are canceled if, by mutual consent, the parties to the relationship decide to end it."11 But what does that mean? We do not usually "decide to end" our friendships. Rather, our ties develop and change, acquire new dimensions, lose others, change gradually. Sometimes these changes amount to a process that would be eventually summed up as: "Pete was a good friend of mine, but we are not close anymore." When asked to refer to his status in my life, I would perhaps talk about him as "my former friend Pete." But there would not be a specific point at which we "ceased to be friends." The process happens gradually. As Aristotle says in his analysis of friendship: "[D]istance does not destroy friendship simply, but the manifestation of friendship. But if the absence be prolonged, it is thought to obliterate even friendship." 12

But suppose there were an exact point at which "our friendship ceased." After all, we do have the notion of relationships that come to an abrupt end, by mutual decision. A married couple can decide to get divorced. We can think of an exact point in time when this decision is reached (suppose they had a long conversation at the end of which they decided to end their marriage), and there is certainly an exact point in time when the divorce itself is officially declared. And yet, the partners' feelings and concern for each other do not cease at these points in time.

Recall that Blustein talks about "the responsibilities of friendship" being "canceled." What do these responsibilities consist in? Some of them might have to do with certain actions that I and my friend used to perform with each other. If we used to share a weekly evening together, these meetings would certainly not take place anymore. But the responsibilities we have towards our near and dear are much more elaborate and deep than these technicalities might suggest. We used to have this weekly meeting because we cared and loved each other. Consider again the example of marriage, and its traditional vows. The husband and wife promise to "love and to cherish" each other. Such feelings cannot be extinguished upon an abrupt decision to "call it off."

My point here is not that we cannot control our feelings and decide whether to have them or not. Indeed, it might be the case that feelings are uncontrollable. But then, what's the point in a vow to "love and cherish" to begin with? Promises about things over which we have no control are simply empty. What our vows manifest, however, is our attitude towards our dear ones. It is as if we say to them: you are very meaningful to me. I love and cherish you now. I want to share my life with you, and I promise I'll do my utmost to still have these feelings towards you many years into the future, "till death do us part."

A wedding is a momentous occasion in which we tend to think specifically about the meaningful people in our lives. Our everyday routine is of course far from such heightened emotion. Many of us simply go through the motions of this routine, without recalling to mind the meaningful people who have helped us become who we are. If

\footnotetext{
${ }^{11}$ Blustein (2008): 241.

${ }^{12}$ Aristotle (1906): 1157a.
} 
Pete dies, his death throws me away from my regular course of life. I pause to consider my life, and his involvement in it, in terms far and beyond everyday matters. This is the reason for my attending his funeral.

But the same must be true not only upon his death, but when I hear of his fatal illness, as in the example we began with. This is the reason for my feeling that I ought to pay him a visit while he is still around. Similarly, an ex-husband might feel obligated to be there for his ex-wife when she is about to die. Suppose that they decided to end their marriage because both of them felt they were not in love anymore. Each of them remarried. Neither of them has had second thoughts. And yet, they used to share the subtlest intimacies with each other. Their lives were most strongly interconnected, and their biographies will ever so be. As their present is partly built upon their past, the connection they used to have is still part of them. Therefore, they have a reason for acknowledging the meaningful past they shared and cherishing it.

The above description is, of course, only one possibility to tell a story about divorce. Perhaps he had been unfaithful. Perhaps she acted in ways that he despised. Perhaps they will never forgive each other, not even when they are on their deathbeds. How they construe what the other party caused them will have to do with the way they portray their expectations from each other. In many cases we cannot make a simple checklist of what such expectations amount to.

Such checklists might be enough for certain definable acts: if I promise to give you 50 dollars tomorrow morning, and I fail to do so, I have not kept my promise. But if I am your friend and you feel depressed, there is no correct answer to the question what I ought to do to improve matters. Of course, the "responsibilities of friendship," as Blustein calls them, will demand that I help you. But in what way? And how much? Will a long conversation over the phone be enough, or should I come and visit? Should I cancel my work plans for the next week so that I can spend the whole time with you? And what exactly should I say to you? Am I allowed not only to encourage, but also to point at various faults of your own which have made you come to this pass? And how exactly should I do so? When will such mention of your shortcomings be considered rude and when should it be regarded as true help? Questions such as these have no "right" answers. They will be decided by the parties to the relationship. If my friend feels that I have not done enough, he will probably ask himself: "what kind of a friend is he?"

Supposedly, we should conclude that as in the case of a current friend, if I do not call upon Pete, he may very well ask himself, "what kind of an ex-friend is he?" But as Pete and I are not friends anymore, it is plausible that he does not have me in mind. To use once again Margalit's terms, it is the people with whom we have thick relationships who form "normative expectations" towards us. Pete does not expect me to call upon him. He would be surprised to receive my call.

This would certainly be the case if Pete's dire situation were not a fatal disease, but rather, let us say, a financial crisis. A fatal disease is a situation for retrospection and reflection. We are reminded of people from the past, and examine the influence they had on our lives. It might thus be claimed that I have chosen a wrong example to prove my point. What is obvious in the case of death, or fatal illness, seems much less so in other cases. 
However, I have chosen these examples deliberately, because of their rather obvious nature. Why does old times' sake play such a role at these extreme circumstances? Because it is then that we tend to think of the people who helped shape our identities. If Pete is in a financial crisis, it is most likely that he will not stop to recall my friendship with him, and will not expect me to do anything for him. But if I do hear about his predicament, I will feel that I have to do something. Pete is no mere stranger. Our shared past is incorporated into the person I have grown out to be. Thus, his predicament concerns $m e$, even if he would not expect me to do anything.

The italicized words in the preceding paragraph - his and me - attest to mine and Pete's shared experience. Carreras suggests in his analysis of Aristotelian friendship that the friend as mirror reflects not me, but rather "us": "that mutually formed character the 'one soul' that we have together made that is now instantiated in each of us." ${ }^{13}$ This, I believe, is going too far. Neither our friends nor our ex-friends have a joint soul with us. But the notion of "us" is nonetheless an important one. What enhanced me in my friendship with Pete was also what enhanced him (this seems to be, as Carreras rightly suggests, Aristotle's main point.) Our old times together were a joint venture. Our past is shared. My reaching out for Pete might be both self-regarding and other-regarding simultaneously. It reflects caring both about him, and about my own past, my own biography, my own accumulated identity.

As with the case of current friendships, there is no definite answer to the question what exactly I should do for Pete. I have spoken at the beginning about "feeling obligated." When no external checklist is available, the "shoulds" and "should nots" are depended upon our feelings and expectations. As in the case of current friendships, one party's feelings and expectations should be juxtaposed with the ones of the other party. Once Pete hears about my intention to help, he might respond in various ways. Perhaps "doing something for him and his family" will be too much, too intrusive, too out of the way. After all, I am not his friend, only his ex-friend. It is reasonable that current friends will be concerned about our doing too little, while ex-friends will be uneasy with our doing too much.

Old times' sake is a reason to act for somebody. It is not a conclusive reason. If the friendship between Pete and me ended because of a bitter quarrel, and Pete is in trouble, I might hesitate. On the one hand, he insulted me so seriously, that I would find it hard to forgive and forget. On the other hand, we shared such good times together, and I cherish what he did for me. Now that he is in trouble, I hardly know what to do. I have two reasons - one against calling upon him and the other for it. But whatever I decide, old times' sake pulls me in one of these directions. It has its moral force.

Old times' sake is of course not the only factor that pulls me in the direction of calling upon Pete. The other one is the fact that he is in trouble. But it is not his trouble per se that would drive me to call upon him. I would not consider paying a visit to other people who are just as fatally ill or in a similar financial crisis but who are complete strangers, or even relative strangers to me. Pete's trouble brings the fact to the fore that our past affinity is still with us. It manifests in a dramatic manner what is true in

${ }^{13}$ Carreras (2012): 329. 
non-dramatic situations as well: the people we used to care about remain a part of our lives even when we do not interrupt our daily routine in order to think about them.

Blustein says that there is no definite answer to the question of how long we should remember our "dear departed." Remembering them means caring for them. If we cease to care, we have no duty to remember. Blustein might very well be right here. But what the story about Pete and me reveals is that notions of care and remembrance might lie deep within our minds, and may come to the surface when extreme circumstances obtain. Deep down I might still care about Pete. When asked about him I certainly recall and remember the value he added to my life. This means that not only his illness, perhaps his death, should make me acknowledge the value he has had in my life. There is a lesson for me to learn right now, in this non-dramatic situation when Pete is probably still well and sound. I should recognize the meaningfulness of old times' sake as a reason for action.

In his analysis of friendship, Aristotle himself recognized the power that the shared past has upon our present. According to his analysis, we should claim "that he [the friend] should not entirely forget their former intercourse, and that just as we hold that we ought to serve friends before strangers, so former friends have some claims upon us on the ground of past friendship, unless extraordinary depravity were the cause of our parting." ${ }^{14}$

Note, however, that there are two ways to go about interpreting our reasons for action according to this quote. It is grounded on "past friendship." Two elements suggest themselves as directing us toward action: the past, and the friendship. It might be claimed that even if my analysis is true, it does not prove that old times' sake is a moral category. Rather, it is friendship that I have paid tribute to. It is the power of my friendship with Pete back then that would affect my actions now. But note that my argument has been built upon the notion of our friends' contribution to the shaping of our identity. Thus, it would be true about other people we used to share our times with, who are not necessarily friends. The example of the ex-spouse is to the point here. Other cases might involve a former colleague or a former neighbor.

Such examples manifest the strength of old times' sake as a moral category. When a friend is involved, one might perhaps use a part of my argument to claim that the notion of an ex-friend is rather blurred. Recall that I said that "there would not be a specific point at which we "ceased to be friends.'" Thus, if I think that I ought to do something for an ex-friend of mine, perhaps it is a proof that in some sense we are still friends, even though we have not seen each other for so many years. But in the case of an ex-colleague or an ex-neighbor, there is a definite negative answer to the question whether we still hold the relationship we used to have. We are not colleagues anymore - we work at different institutions. We are not neighbors anymore - we live in different cities.

The fact that our courses of life mingled in the past is accidental. Living here rather than there, having this person as a neighbor rather than that one, are facts that have a bearing on the question for whose sake we choose to act. Such particular circumstances bring down to earth our general moral obligations. ${ }^{15}$ In Kantian terms, we have a uni-

${ }^{14}$ Aristotle (1906): 1165b.

${ }^{15}$ I owe the emphasis of this point to an anonymous reviewer. 
versal duty of beneficence. But whom should we bestow it upon? According to Kant, "men are to be considered fellow-men - that is, rational beings with needs, united by nature in one dwelling place for the purpose of helping one another."16

"Men" here are everybody. And the "dwelling place" is the entire world. But in actuality, we encounter one person or another. And our dwelling place is this neighborhood, this street, this block. Over the years we change our dwelling place, and cease to meet with the people we used to. Our lives have drifted apart. But back then she had an important impact on my being. I still cherish the experiences we shared. I should think favorably about her. I might even give her a call. Just for old times' sake.

\section{Bibliography}

Aristotle (1906), The Nicomachean Ethics, trans. F.H. Peters, Kegan Paul, London.

Blustein J. (2008), The Moral Demands of Memory, Cambridge University Press, New York.

Carreras A. (2012), "Aristotle on Other-Selfhood and Reciprocal Shaping," History of Philosophy Quarterly 29 (4): 319-339.

Cocking D., Kennett J. (1998), “Friendship and the Self," Ethics 108 (3): 502-527.

Crépel A.-L. (2014), “Friendship: Shaping Ourselves," International Journal of Philosophical Studies 22 (2): 184-198.

Kant I. (1964), The Doctrine of Virtue: Part II of the Metaphysic of Morals, trans. M.J. Gregor, University of Pennsylvania Press, Philadelphia.

Margalit A. (2002), The Ethics of Memory, Harvard University Press, Cambridge, Massachusetts, London.

Murphy J. (1982), "Forgiveness and Resentment," Midwest Studies in Philosophy 7 (1): 503-516.

Richards N. (1988), "Forgiveness," Ethics 99 (1): 77-97.

Stroud S. (2016), “Epistemic Partiality in Friendship," Ethics 116 (3): 498-524.

${ }^{16}$ Kant (1964): 121. 